Alison Butler is an economist at the Federal Reserve Bank of

St. Louis. Lora Holman provided research assistance.

\title{
The Trade-Related Aspects of Intellectual Property Rights: What Is At Stake?
}

The pirating of U.S.financed research and development discourages innovation, denies markets to American exports, and threatens technological progress. Protection of intellectual property rights preserves America's technological edge, which is a key to our continued international competitiveness."

-Clayton Yuetter,

U.S. trade representative, 1986

\begin{abstract}
Ting
1. HE SENTIMENTS expressed by the former U.S. trade representative above could have easily been made by trade representatives from any industrialized country about their own country. In the last few years, many industrial countries have become increasingly concerned over the lack of international protection of intellectual property rights (IPR).
\end{abstract}

In a 1988 study, the U.S. International Trade Commission (USITC) attempted to estimate the economic effects of intellectual property rights infringement by foreign countries on U.S. firms. ${ }^{1}$ In its survey, firms estimated their losses at $\$ 6.2$ billion in exports sales in 1986 . These losses accounted for approximately 1.4 percent of the total export sales of products which are covered by some form of intellectual property rights that year. Firms estimated additional losses of $\$ 1.8$ billion in sales in 1986 due to imports that in- fringed on their domestic IPR. In a related study, Feinberg and Rousslang (1990) estimate that the ratio of lost profits to worldwide sales of firms selected from the USITC study ranged from 0.05 percent for the extractive sector to 3.6 per- $^{-}$ cent for the entertainment sector. ${ }^{2}$ Since firms incur research and development (R\&D) expenses to develop intellectual property, these lost sales and profits defer firms from undertaking the risky process of developing intellectual property in the future.

Frustrations over the lack of effective international agreements regarding IPR have led the United States to unilaterally create measures to deal with what it perceives as unfair trading practices. In particular, the so-called "Special 301" clause of the Omnibus Trade and Competitiveness Act of 1988 requires the U.S. Trade Representative to identify countries that do not

1USITC (1988). For limitations of the survey and data, see the study.

2See also Feinberg (1988). 
adequately protect or enforce IPR. The trade representative then has the authority to bring an unfair trade practice case against that country. Although several countries have been put on a "priority watch list," no cases have yet been initiated by the U.S. Trade Representative under the "Special 301" designation.

Countries throughout the world, particularly the more industrialized ones, are interested in increasing the amount of protection and enforcement of IPR internationally. Their concerns are seen in the current negotiations of the General Agreement on Tariffs and Trade (GATT). GATT is the principal rule-making body for international trade, whose goal is to eliminate trade barriers that reduce the free flow of goods. In the current round of negotiations, the so-called Uruguay Round scheduled to end in December 1990, one of the 15 negotiating groups is devoted to developing an agreement regarding "traderelated aspects of intellectual property rights, including trade in counterfeit goods."3 Currently, intellectual property rights are explicitly excluded from GATT's auspices.

There are many economic and legal issues related to the protection of intellectual property. ${ }^{4}$ The analysis in this paper focuses only on the trade-related aspects of IPR, that is, the effect of differential (and uncertain) IPR across countries on trade and the benefits and costs of creating international standards for protecting intellectual property.

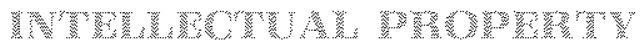

Intellectual property is an invention, idea, product or process that has been registered with the government and that awards the inventor (or applicant) exclusive rights to use the invention for a given period of time. It confers "...the right to exclude others from making, using, or selling the invention within the national territory." (For a discussion of why intellectual property is awarded protection, see shaded insert on pages 39 and 40 .) Industrial property protection is generally awarded only to new and useful products and production processes. Intellectual property is protected by the government in a variety of ways. Copyrights are awarded to protect original works of authorship, such as literary, artistic and musical works; trademarks allow a manufacturer exclusive rights to a distinguished name, symbol or mark..$^{6}$ As noted above, these rights are only valid in the countries in which a patent application has been awarded. This lack of an international IPR system could have a significant impact on the amount of innovative activity. ${ }^{7}$

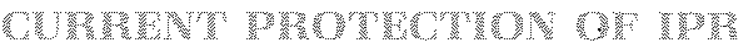

The protection awarded different types of intellectual property varies substantially across countries. As shown in table 1 , most countries have patent lengths of 15 years or more. ${ }^{8}$ Historically, an innovation was awarded patent protection for the number of years approximately equal to the amount of time it took to train two apprentices (14 years). ${ }^{9}$ Although the apprentice system has been obsolete for many years, patent lengths have remained essentially unchanged.

Often, however, the actual period in which a firm can sell its product under patent protection is shortened considerably; for example, tests for
3GATT (1990), p. 11.

4 For a discussion of some of the legal issues regarding IPR in international trade, see Meessen (1987). To narrow the focus of the paper, two issues have been ignored: which items should be protected by intellectual property regula tions and what type of protection-patents or copyrightsis appropriate for certain types of goods, such as software. 5USITC (1988).

6Other types of intellectual property, such as trade secrets and mask works, constitute a small percentage of all intellectual property and are not discussed here. In addition, because there are no internationally agreed-upon definitions for intellectual or industrial property, these definitions should be considered chiefly as guidelines.

7 Intellectual property protection is important insolar as innovation is desirable. Some analysts argue (see, for example. Nordhaus, 1969; Grossman and Helpman, 1989) that innovation increases growth worldwide, improving the quality of life through such things as better medicines, improved living conditions and safer production processes. of course all innovations may not be beneficial, nor do all people necessarily benefit from all innovations (see, for example, Karnien and Schwartz, 1982 and Maskus, August 1990). In this paper, it is assumed that innovation has a net positive effect on a country's growth and on growth worldwide.

aAl countries referred to are members of the World Intellectual Property Organization (WIPO). All statistics in this section, unless otherwise cited, are from WIPO (1988).

'Benko (1987). 


\section{Table 1}

\section{Domestic Protection}

\begin{tabular}{|c|c|c|}
\hline Intellectual propenty & $\begin{array}{l}\text { Number of } \\
\text { countries }\end{array}$ & General length \\
\hline Patents' & 28. & $\begin{array}{l}5-10 \text { years } \\
1045 \text { years }\end{array}$ \\
\hline Copylights? & $\begin{array}{l}8 \\
76 \\
9\end{array}$ & $\begin{array}{l}25 \text { years } \\
50 \text { years } \\
50+\text { vears }\end{array}$ \\
\hline
\end{tabular}

Trom date hlod

2from author's death.

SOURCE. World Intellecual Property Organization (1988) product safety (which, for pharmaceuticals, can take up to 10 years) are included in the life of a patent. Recently, both the United States and the European Community proposed legislation that would increase the effective length of patent protection-that is, the amount of time a firm can actually market or use a product before its protection expires. ${ }^{10}$

Several additional factors affect the amount of protection intellectual property is awarded in any given country. As tables 2 and 3 show, many countries, including some industrial ones, exclude certain industries from patent protection. Those excluded are primarily high-technology industries with very high R\&.D intensities that tend to produce expensive products. Although currently a substantial amount of innovation oc-

ioSee Congress and the Nation (1985) and "Patents for Pharmaceuticals" (1990).

Table 2

\section{Patent Exclusions}

\section{Product}

Pharmaceutical products (PHARM)

Animal varieties (ANIM)

Methods for treatment of humans or animals (TREAT)

Plant varieties (PLANT)

Blological processes producing

plant or animal varieties (BIO)

Food products (FOOD)

Computer prograns (COMP)

Chenical products (CHEM)

Nuclear inventions (NUC)

Pharmaceutical processes

Food processes

Microorganisms

Substances from nicrobiological processes

Cosmetics

Fertilizers

Mixture of metals and alloys

Agricultural nachines

Anticontaninants

Methods of agficufture or

horficulture

\begin{tabular}{|c|c|c|}
\hline $\begin{array}{l}\text { Number } \\
\text { of counures } \\
\text { that exclude }\end{array}$ & $\begin{array}{l}\text { Industrial } \\
\text { countries? }\end{array}$ & Industrialized \\
\hline 47 & 8 & $170 \%$ \\
\hline 59 & 18 & 30.5 \\
\hline 59 & 18 & 30.5 \\
\hline 57 & 18 & 316 \\
\hline 56 & 18 & 321 \\
\hline 34 & 8 & 235 \\
\hline 48 & 20 & 417 \\
\hline 21 & 2 & 9.5 \\
\hline 13 & 2 & 154 \\
\hline 10 & 2 & 200 \\
\hline 9 & 3 & 333 \\
\hline 8 & 1 & 125 \\
\hline 6 & 1 & 167 \\
\hline 2 & 0 & 0,0 \\
\hline 2 & 0 & 0.0 \\
\hline 2 & 0 & 00 \\
\hline 1 & 0 & 00 \\
\hline 1 & 0 & 00 \\
\hline 1 & 0 & 00 \\
\hline
\end{tabular}

These are the Western European countries, Japan, Canada, Australla United States, New Zealand and lceland.

SOURCE, World Intellectual Property organization (1988) 
Table 3

\section{Selected Patent Exclusions by Country}

\begin{tabular}{|c|c|c|c|c|c|c|c|c|c|}
\hline Countries & PHARM & ANIM & TAEAT & PLANT & B10 & FOOD & COMP & CHEN & NUC: \\
\hline Australta & $x$ & & & & & $\mathrm{x}$ & $x$ & & \\
\hline Austria-Belgium & & $x$ & $x$ & $x$ & $x$ & & $x$ & & \\
\hline Canada & & $x$ & $x$ & $x$ & $x$ & $x$ & $x$ & & \\
\hline Denmark & & $x$ & $x$ & $x$ & $x$ & $x$ & $x$ & & \\
\hline Finland Norway & $x$ & $x$ & $x$ & $x$ & $x$ & $x$ & $x$ & & \\
\hline France & & $x$ & $x$ & $x$ & $x$ & & $x$ & & \\
\hline Germany & & $x$ & $x$ & $x$ & $x$ & & $x$ & & \\
\hline Greese & $x$ & $x^{1}$ & $x^{1}$ & $x^{t}$ & $x^{1}$ & 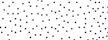 & $x$ & & \\
\hline loeland & $x$ & & & & & $x$ & & & \\
\hline Ireland & & & & & & & & & \\
\hline maly? & & $x$ & $x$ & $x^{\prime}$ & $x$ & & $x$ & & \\
\hline Japan & & & $\mathrm{x}$ & & & & $x$ & & $x$ \\
\hline Luxentoourg & & $x$ & $x^{\prime}$ & $x$ & $x$ & & $x$ & & \\
\hline Netherlands & & $x$ & $x$ & $x$ & $x$ & & $x^{1}$ & & \\
\hline New zealand & $x$ & & & & & $x$ & & & \\
\hline Portugal & $x$ & $\mathrm{x}$ & 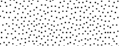 & $\propto$ & $x$ & $x$ & $x$ & $x$ & \\
\hline Span & 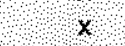 & $x$ & $x$ & $x$ & $x$ & & $x$ & $x$ & \\
\hline Sneden & & $x$ & 8 & $x$ & $x$ & & $\mathbf{x}$ & & \\
\hline Swlzerlandz & & $x$ & $x$ & $x$ & $\times$ & & $x^{3}$ & & \\
\hline United Kingdom & & $x$ & $x$ & $x$ & $x$ & & 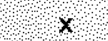 & & \\
\hline United States & & & & & & & & & $x$ \\
\hline Tolal & 8 & 18 & 18 & 18 & 18 & 8 & 20 & 2 & 2 \\
\hline Developing & & & & & & & & & \\
\hline & & & & & & & & & \\
\hline Asian & 13 & 6 & 8 & 6 & 5 & 7 & 2 & 6 & 3 \\
\hline Indla & 4 & 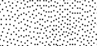 & $\mathrm{x}$ & 8 & & $x$ & & x & 8 \\
\hline Indonesia & & & & & & & & & \\
\hline Pakstan & $x$ & & & & & & & & \\
\hline Rep of korea & $x$ & & & & & $x$ & & $x$ & $x$ \\
\hline Ihailand & $x$ & $x$ & & $x$ & $\mathrm{x}$ & $x$ & $x$ & & \\
\hline Atrcan & 8 & 20 & 18 & 20 & 20 & 5 & 18 & 1 & 0 \\
\hline Westert lemisphere & 10 & 8 & 7 & 8 & 8 & 8 & 2 & 6 & 3 \\
\hline $\mathrm{Braz} / \mathrm{P}$ & $\mathrm{x}$ & $x$ & $x$ & $\mathrm{x}$ & $x$ & $x$ & o. & $x$ & x \\
\hline Mexico & $x$ & $x$ & $\varnothing$ & $x$ & $x$ & $x$ & $x$ & $x$ & $x$ \\
\hline Venezuela & 8 & & & & & 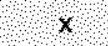 & & $x$ & \\
\hline European & 8 & 7 & 8 & 5 & 5 & 6 & 6 & 6 & 5 \\
\hline Eastern & 7 & 4 & 5 & 4 & 2 & 6 & 3 & 6 & 5 \\
\hline Total & 39 & 41 & 41 & 39 & 38 & 26 & 28 & 19 & 11 \\
\hline TOA & 47 & 59 & 59 & 57 & 56 & 34 & 48 & 21 & 13 \\
\hline
\end{tabular}

NOTE See table 2 for definitions.

If fled through the European Patent Gonvention (EPC)

2ncludes Llechtenstein

LLechtenstein excludes If filed through the EPC.

SOURCE World Intellectual Property Organization (1988) 
curs in some excluded industries-for example, genetic engineering-it generally takes place in countries that do not exclude them from protection. For example, although European firms account for 82 percent of world investment in industrial plant and other biotech assets, only 2 percent of it was spent in Europe. Similarly, 77 percent of all patents in biotechnology were issued in the United States and Japan, which offer the most extensive patent protection. ${ }^{11}$

The length of copyright protection, on the other hand, is a more standardized measure across countries, with the majority of countries issuing copyright protection for the remainder of the author's life plus 50 years.

Other factors that influence the extent of protection for intellectual property are the enforcement of existing laws and the amount of copyright and patent protection in other countries. These factors are particularly important when examining the trade-related aspects of IPR.

\section{WDA

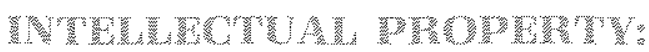

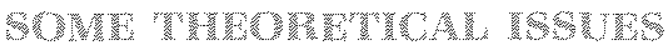

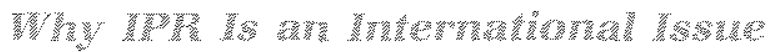

The problem with the lack of an international system of rules regarding IPR occurs when the cost of copying an innovation (including the cost of penalties if caught) is less than that of either purchasing or leasing the technology itself.

There are primarily two ways that a product patent can be infringed upon: First, a copy of the product can be produced, with essentially the same characteristics (although not necessarily the same quality) as the original, but with no pretense of being the original product. Typically, such copies are sold at a lower price. An example of this occurred in 1976 when Kodak introduced a line of instant cameras that were similar to those already patented by Polaroid. In 1986, U.S. courts ruled that Kodak had infringed on Polaroid's patents and awarded the Polaroid
Company $\$ 5.7$ billion; this amount was reduced to $\$ 909.5$ million in 1990 on appeal.

The second type of patent inf ringement would occur if a company produced a camera similar to Polaroid's and labeled and sold it as a Polaroid. This is an example of a "counterfeit" product. In this instance, Polaroid's trademark as well as its patents would be infringed upon.

International trade can affect even non-traded products that are protected by IPR. For example, suppose a pharmaceutical firm, call it SAW, recently developed a new product called NOCOLD, that cured the common cold and had no side effects. If the firm intended only to sell NOCOLD in its own country (call it the North), it would file for a patent only in the North.

Even if SAW does not export NOCOLD, however, the rate of return earned could be affected by international trade. For example, a firm in another country could create either a counterfeit version or a cheaper imitation of the product and export it to the North. ${ }^{12}$ Similarly, a country that is producing NOCOLD legally could export it back to the North. ${ }^{13}$ If sales of the foreign-produced product in the North reduce SAW's sales of NOCOLD and its profits on the product, the firm would expect a lower return on NOCOLD as well as all prospective products. Because the expected rate of return affects the decision to develop new products, the firm undertakes fewer projects in the future. Thus, protecting intellectual property is not just a domestic issue.

If the company that infringed upon a patent in either of the two ways was not a U.S. company, the patent laws in both the United States and the country in which it was located would have to be considered. Unless an agreement states otherwise, a patent or copyright is valid only in the country in which tt was issued. ${ }^{14}$ Thus, if Kodak had produced and sold its cameras in countries that did not honor Polaroid's patent, Polaroid would have been unable to sue Kodak. Because many patent violations occur across national borders, differences in pa-

\footnotetext{
11 "Bugs that Divide" (1990).

12Not all countries have made it illegal to import products that infringe on domestic paients.

¥Parallel trade, which occurs when a product produced under a patent in one country is exported to another country and competes with the patented product in that country, is legal in many countries and for intra-EC trade.
}
14There are surprisingly few agreements among countries to honor each other's patents. This is discussed in greater detail later.




\section{The Economics of Innovation}

There are essentially two types of techno. logical innovations: process innovations, which are new production processes or inprovements on existing technology and product innovations, which are the creation of new pro ducts or improvements on existing products: Both types of innovation are patentable Because the economics of these two are essen: trally the same, the discussion focuses on production innovation for simplicity.

Intellectual property has the unusual (al. though not uniquel property that the know. ledge it contains is not depleted with use. For example, no matter how many times the for: mula for aspirim is used, the formula itself that is, the knowledge contained in the pa: tent) remains unchanged. As a result the narginal cost of using this knowledge ( $\mathrm{g}$ : . the formula for aspirin is zero. for economic efficiency. this knowledge should be nade available to anyone interested, because doing so does not diminish the stock of knowledge for reduce the number of times aspirin can be made). Over time, however, such a policy would have some unfortunate consequences.

Generally, imnovation is the result of invest. ment expenditures on research and develop. ment (R\&D). Because expenditures on R\&D eceur before a new product is er eated, the firm's decision to incur these costs involves considerable uncertainty. The expected rate of retum on R\&D, which is the present dis: counted value of the stream of net operating profits divided by the present value of the RidO costs, has to be at least as great as the opportunity cost of resources devoted to R\&D-that is, the expected rate of return that would have been earned if the same resources allocated to Ri\& W were invested elsewhere:
While the opportunity cost of capital is easy to determine (it is simply the interest rate), the rate of retum on R\&D is more difficult to ascertain. It depends on how much R\&D must be spent before a new product is discovered and developed, how nuch demand there will be for the new product, and how much production costs will be. The return on RED also depends on the time the firm can produce the product exelusively and there: fore earn econonic profits. While the first three factors are outside the scope of this paper, the last faetor demonstmates how IPR can effect the incentive to innovate.

In the absence of government intervention, maintaining exclusive rights to an imovation for any period of time is often diffrcult. Given that the marginal cost of using the knowledge created by the innovation is zero, one could conclude that governments have no reason to award these rights. Without assigning exclusive rights to produce the innovation, how ever, the amount of time the imovating firm can produce the product is both less certain and likely shorter any other firm that can figure out how to make the product could also produce it without changing the know: ledge associated with the imnovation. For ex ample, a firm that did not discover the for: mula for aspirin but, instead, was able to produce it would reduce the return eamed by the innovating firm. This is true even though entry by the noninnovating firm in this market does not diminish the innovating firm's ability io produce aspirin. This reduced return on the investment in R\&D appears to increase efficiency by promoling competition, however, it also reduces the number of Rid. projects that will be undertaken. If however. the govermment assigns property rights to

The economic reasons tor copyrtaht prolectlon, essen. trally the same as those tor patent protection, are not discussed separately. The reasons for protecting trademerks. however, ditter trom hose tor patent and copyrights, as tradenarks are thought to provide nfor matien tor consumers about he quality of a product. Protedion of ltadenarks is ntended to ensure thet hey have some informative value to consuners, rather than to proted an idea itselt? 
innovations (and enforces them), then the amount of time the product can be produced exclusively will increase, raising the rate of return on R\&D, which in turn has a positive effect on the amount of innovation.

Of course, the world is not certain. There is no way of knowing in advance whether the R\&D expenditures will produce an economically viable product. intellectual proper- ty rights are a way of rewarding firms for in curring the risk associated with $\mathrm{R} \& \mathrm{D}$ by in creasing the expected rate of return on R\&D, thereby naking nore projects possible.

As long as innovation is considered desirable, assigning property rights to intellectual property is one way to encourage firms to innovate ${ }^{3}$
2There is some disagreement as to how much IPR increases infovation (see, tor example, Maskus, 1990) The question is a difficult one to measure empirically because it requires determining what a firm would do in a situation that has not occurred One attempt to do so is Mansfield (1986), who finds some role tor patents thencouraging nnovation.
SFor a general discussion of the role of R\&D on hnova tion, see Kamien and Schwatz (1982), In addition, the issue of determining the optimal length and breadth of a patent (within a countr) has recently been dis cussed In the RAND Jownat of Economics (Sping 1990) and Economic hquiry (October 1984 ). tent laws across countries and the lack of an international enforcement system affects the incentives associated with innovation.

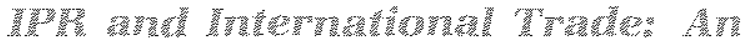

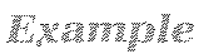

Suppose that SAW wanted to sell NOCOLD internationally as well. A firm can do this one of three ways, all of which are affected by the state of international property rights. For simplicity, the example below compares the case in which only one of the two countries protects IPR.

wayer NOCOLD directly to another country, which we will call the South. If the product is not protected by a patent in the South, either because SAW has not filed for protection there or because the South does not protect IPR, cheaper copies that use the same formula as NOCOLD could be legally sold. Similarly, if the trademark is not protected, counterfeit products that are indistinguishable from NOCOLD can also be legally sold. These copies decrease SAW's total sales and profits associated with producing and selling NOCOED. In addition, if the product has a trademark that is strongly associated with SAW, the counterfeit product, if of significantly poorer quality, could adversely affect the reputation of the firm and further harm the sales of both NOCOLD and future products of SAW.
I. gy to produce NOCOLD to a firm in the South. The Southern firm, in turn, pays SAW a royalty fee. Without protection of IPR, however, a firm has no incentive to pay licensing fees if it is cheaper to copy the product than pay those fees. For industries where licensing represents a significant proportion of its revenues, the lack of IPR can cause a substantial loss of revenue for a firm. For example, motion picture firms receive considerable revenues from licensing fees paid by foreign distributors. Every "pirated" copy of a movie that is sold or shown represents a loss of revenue for the movie company, 1.5

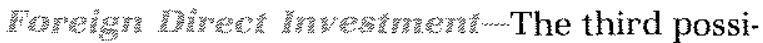
bility, called foreign direct investment, occurs if SAW locates production facilities in the South to produce NOCOLD. Again, however, the lack of IPR in the South has a similar effect on innovation as discussed previously. Because SAW has no guarantee that it can control the production of NOCOLD in that country, the expected rate of return on the innovation is smaller, reducing the profitability of foreign investment in the South; as a result, fewer firms will engage in such foreign direct investment. A country's lack of adequate protection of IPR could be particularly costly in this case because the country is foregoing some of the benefits of foreign direct investment, such as new resources, training and

15For a discussion of the effects of international piracy in motion pictures in the United States, see USITC (1988) and Plock (1989). 
employment. Obviously, counterfeiting firms might provide some of these same benefits; since they develop no new products themselves, however, they are dependent on others for innovations to copy. ${ }^{16}$

As long as the direct cost of counterfeiting (or copying), including the likelihood and penalties associated with being caught, is less than the profits earned by the firms doing the copying, firms will continue to pirate technology. Copy. ing, however, lowers the rate of return earned by innovators and therefore the overall amount of innovation. In the long run, the resulting decline in the amount of innovation reduces the counterfeiting that can be done by firms in the South. On an aggregate level, the citizens of both countries end up worse off. There is less innovation, fewer products overall, and worldwide growth is therefore lower.

While the vast majority of countries have laws protecting intellectual property, the arguments presented above describe what occurs in countries that either have weak IPR or simply fail to enforce whatever IPR they do have. Given the apparent advantages of protecting intellectual property, why are there so many problems with trade in goods affected by intellectual property rights? Part of the answer to this question can be found by examining the current international system of regulating intellectual property rights.

\section{CDI

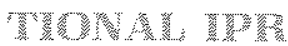

The main organization responsible for international agreements on IPR is the World Intellectual Property Organization (WIPO), which is administered under the auspices of the United Nations. WIPO's objectives include administering international treaties and agreements on intellectual property rights and encouraging the protection of IPR worldwide. ${ }^{17}$ Currently, 125 coun. tries are members of WIPO. ${ }^{18}$ Table 4 provides a partial list of these countries and of signatories of several treaties administered by WIPO. The two major international agreements on IPR are the Paris and Berne Unions, which deal with industrial property (including patents) and copy. rights, respectively. (For a description of the two agreements, see shaded insert on page 43.) In addition to these unions, other international property right agreements administered by WIPO cover such things as industrial design, satellite transmissions and registration of trade and service marks. ${ }^{19}$ Not all members of WIPO, how. ever, are signatories to these unions and treaties, nor are the number of signatories for each agreement identical (see table 4 ). ${ }^{20}$

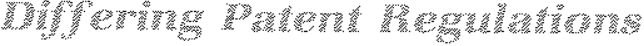

One important issue regarding the trade-related aspects of intellectual property is the problem of differential patent regulations across countries. For example, while most countries determine patent eligibility based on a first-to-file basis, the United States employs a first-to-invent rule. As a result, patent protection for the same invention could be awarded patent protection to different applicants depending on whether the actual inventor was the first to file.

WIPO has had some success in trying to standardize the process of obtaining patents internationally through the Patent Cooperation Treaty (PCT). This treaty allows applicants to file for a patent in a central office and specify in which of the signatory countries (shown in table 4) it wishes the application to have effect. This process reduces the costs of filing for patents by centralizing the search and examination work associated with determining patent eligibility. The PCT is also designed to increase the time an applicant has to decide whether to withdraw the application for foreign patents. A firm might choose to withdraw its patent application and avoid the expense associated with translating the patent application into the local language and finding a local patent agent if the demand for the product to be patented is likely to be too small.

\footnotetext{
16 Whether or not foreign direct investment is desirable tor developing countries is a separate issue and is discussed elsewhere. (See, for example, Hood and Young, 1979.) For the purposes of this paper, we assume that the lack of IPR does not mean a country doesn't want toreign direct investment-there are more straight-forward ways to reduce or eliminate foreign investment.

17For a list of organizations that are solely administered by WIPO, see WIPO (1988), p. 8.
}

18These statistics exclude the German Democratic Republic because of the unification with the Federal Democratic Republic that occurred on October 3, 1990.

19See WIPO (1990a).

20The United States, for example, did not sign the Berne Union until 1988 


\section{Table 4}

\section{Signatures of Selected International Intellectual Property
Agreements}

\section{Inctustrialized}

Countries

\section{Australla}

Austria Belgium

Canada.

Denmark

FinandNorway

France

Germany

Greece

lcoland

Ireland

rtaly

Japan

Luxembourg

Netherlands

Now Zealand

Portugal

Spain

Sweden

Switzerland?

United Kingdom

United States

Total

Developing

countries

Asian:

india.

nodonesia

Pakistan

Rep, of Korea

Thailand

\section{Atrican}

Western Herisphere

Brazll

Mexico

Venozuela

$$
\text { European }
$$

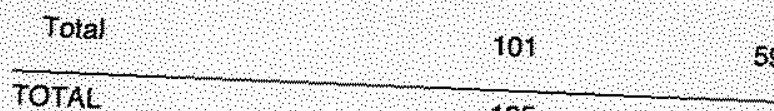

Dominican Republic, han, Nigeria San Marino and Syra are nol nembers of WiPO

3 Hong Kong, singapore and taiwan are not members of WiPO

SOURCE Word ntellectual Property Organization (1990a)

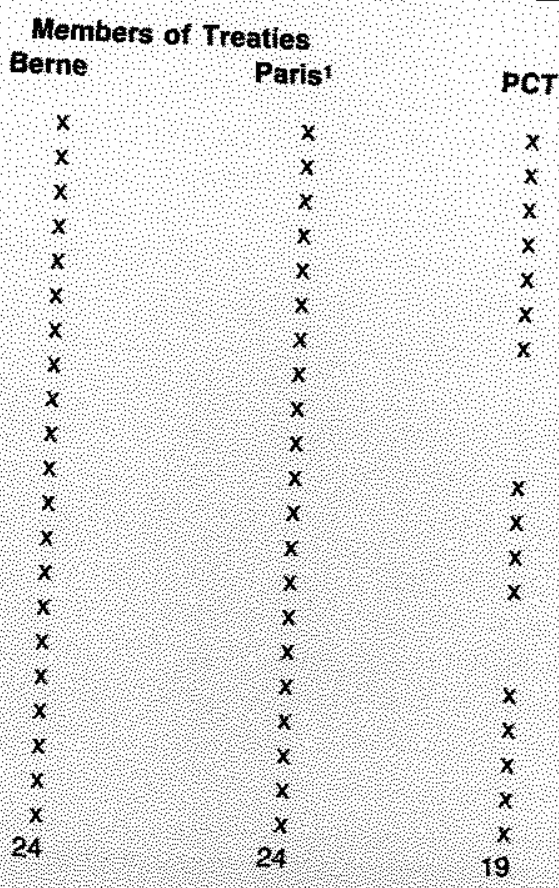

\section{9}

$x$

17

?

$x$

35

14 ४ै?

?

$\mathrm{x}$

1

12

21
14

4

3

${ }_{4}$

2

$x$

43 


\section{The Paris and Berne Unions: Some Background Information}

The Paris Union, the official name of which is the International Union for the Protection of Industrial Property, was founded by a Convention signed in Paris in 1883 and last revised in 1967

Under the Convention, each nember State must accord the same protection to the inventions, trademarks and other subject matter of industrial property of the nationals of the other member states as it accords to those of its own nationals. The Convention also provides certain facilities to foreigners; for example, it allows them, without losing their claim to novelty, to file their applica. tions for patents up to a year after first filing in the country of origin. It contains provi. sions concerning the conditions under which a State may license the use of a patented invention in its own territory if, for example, the owner of the patented invention does not exploit it in such territory.

The Berne Union, the official name of which is the International Union for the Protection of Literary and Artistic Works, was founded by a Convention signed in Berne in 1886 and last revised in 1971.

Under the Convention, each member State must accord the same protection to the copy. right of the nationals of the other nember States as if accords to that of its own nation als. The Convention also prescribes some minimum standards of protection; for example, that copyright protection generally con. tinues throughout the author's life and for 50 years thereafter It includes special provisions for the benefit of developing countries:

WIPO, General Information, 1990
Ninety percent of all patent applications are filed in the 43 countries that make up the mem. bership of the PCT ${ }^{21}$ The usefulness of the PCT is demonstrated by the surge in the number of applications received by the PCT, from 2,625 in 1979 to 14,874 in $1989 .{ }^{22}$ In addition, the number of countries designated for patent protection by applicants rose from 6.6 percent to $\mathbf{1 5 . 8}$ percent of member countries during the same time period.

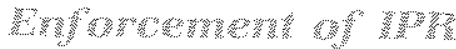

As mentioned previously, the enforcement of existing IPR is another big problem. Although WIPO administers several international accords regarding IPR, few laws currently enforce these treaties. The Paris Union only requires signatories to give foreigners national treatment, that is, award them the same rights as they give their own citizens.

The Berne Convention includes two enforcement provisions. First, it established the presumption of authorship so that the author does not have to prove it; rather, challengers of the copyright would have to provide evidence to the contrary. Second, copies that infringe on a copyright are subject to seizure in any country in which the work has a copyright. This also applies to imports of reproduced materials from countries where the work is not protected.

WIPO does not have an international dispute settlement mechanism whereby an applicant for country) can file a complaint against another country's implementation of the treaties. The only recourse under the agreement is to bring a case before the International Court of Justice. ${ }^{23}$ That court, however, can only arbitrate cases
21The statistics in this section are from WIPO (1990a, 1990b).

22The potential of this agreement has just begun to be realized. For example, the United States, which is a signatory of the PCT, had 66,850 applications for patents by foreigners. (U.S. Department of Commerce, Patent and Trademark Office, 1989).
23The court's ruling is not binding for anl members, however See WIPO (1988). 
that relate to the interpretation or application of the Paris and Berne Unions. There appears to be no penalty for ignoring the ruling of the Court.

WIPO does require countries to give applicants access to the same legal remedies for patent infringement as they do their own nationals. This requirement, however, is subject to existing laws for patent violations. In fact, many countries do not have explicit penalties associated with violations of IPR, and few impose civil penalties. According to WIPO, as of 1988 , only 14 countries had laws requiring the seizure of infringing patent articles, 20 countries granted compensation of damages and 11 destroyed infringing goods. There is somewhat more protection for products with trademarks. WIPO is now preparing a study that will examine the possibility of establishing a new treaty which creates a dispute mechanism to arbitrate possible violations of international IPR agreements.

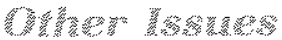

The problems described above explain why there is considerable concern about the current international system of IPR. Having an international set of rules regarding the protection of intellectual property reduces the uncertainty associated with innovation and increases the expected return earned on those innovations. This does not mean that all countries must have the same degree of protection-GATT, for example, has different rules regarding the acceptable amount of tariffs for industrial and developing countries. Rather, an explicit set of agreements, along with an effective mechanism to mediate disputes, could significantly decrease the loss of earnings associated with copying and counterfeiting innovated products. In addition, such agreements could reduce the information costs of determining the amount of protection of intellectual property. These costs can be substantial for firms that intend to sell their products internationally, and, as described above, must file for a patent in each country where it wants to sell the product. Similarly, given the current system in which countries can choose to ex- chude specific products from patent protection, firms are faced with the choice of selling their products in some markets with no protection or avoiding certain markets altogether. Developing countries that protect IPR will increase its access to new technology because innovating firms will have stronger incentives to produce and sell their products in countries that protect intellectual property.

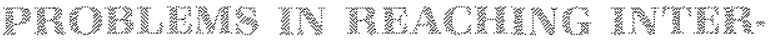

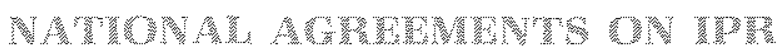

Why are there so few (and such weak) international agreements on IPR? One primary difficulty in protecting and enforcing IPR is that the incentives to do so differ across countries, particularly between countries that are technology exporters and those that are technology importers. ${ }^{24}$ Generally, less innovation occurs in developing countries; instead, in the absence of licensing or foreign direct investment, firms in these countries tend to produce goods whose production technology has become standardized or whose patent protection has expired.

Firms that successfully pirate technology in many developing countries are often able to produce essentially the same product at substantially lower production costs. Because there is less innovation in developing countries, the cost of not protecting IPR (reduced future inno. vation) is often less, at least in a static sense, than the gain associated with selling these products.

An argument of ten made by developing countries is that there is "excessive" protection of IPR in industrial countries. The optimal amount of protection of intellectual property is difficult to determine within a given country. This issue becomes more complicated in an international context, because what is optimal from a domestic perspective may not be optimal from an in. ternational standpoint. For example, even from a long-run perspective, the optimal amount of IPR protection can differ across innovating and non-innovating countries. ${ }^{2.5}$
2aThis terminology comes from Maskus (1990). This analysis can also be used within a country, where some regions have industries with a lot of innovation (such as the Silicon Valley in Callfornia), and others have very few innovating industries. For an example of a model that looks at innovation and technology transfer both within and across countries, see Butler (1990).

${ }^{25} \mathrm{Chin}$ and Grossman (1988), for example, find that the desired amount of protection between innovating and noninnovating countries depends on the specification of social welfare used and that strong IPR may not improve global efficiency. Diwan and Rodrik (1989), in a different theoretical framework, also find that the optimal amount of protection between the innovating and non-innovating countries coincide only if welfare in the two regions is weighted equally. 
Many poorer developing countries find it difficult to pay the higher price innovated goods would cost if they are given patent protection in their country. Developing countries therefore have little incentive, at least in the short run, to protect commodities they need (or want) but could not afford to buy if protection is awarded. An example of this is seen in the pharmaceutical sector, which is awarded patent protection in essentially all industrial countries, but not in many poorer developing countries, which might otherwise have difficulty purchasing medical supplies.

Another argument for not protecting IPR in technology-importing countries is that reverse engineering, the process by which firms take products apart to learn how to produce them, enables firms to learn how to develop new products themselves and therefore aids in a country's development. As the technological knowhow improves in a country, these firms begin to innovate themselves. When this stage is reach. ed, protection of IPR generally begins to increase. ${ }^{26}$

Given the current level of protection of IPR, creating increased standards of protection, at least in the short run and for the least-developed countries probably in the long run, will redistribute income from technology-importing, developing countries (whose residents will now have to pay more for these types of products) to countries which innovate or already protect IPR. As a result, success in negotiating increased international protection for IPR will likely require some concessions to the developing countries in other areas of trade. ${ }^{27}$ These issues are currently being discussed by WIPO and GATT.

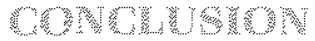

The incentive to protect intellectual property rights, as well as the actual amount of protection awarded, differs widely across industrial and developing countries. Nevertheless, recent negotiations under WIPO and GATT (which, as of this writing, is yet to be concluded) regarding the trade-related aspects of intellectual property rights indicate increased support for international agreements on intellectual property rights and a realization that such agreements benefit both industrial and developing countries. In addition, as the amount of inventive activity and the number of countries engaged in innovation increases, the trend toward more cooperation and protection of intellectual property is likely to continue.

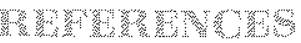

Benko, Robert P. "Intellectual Property Rights and the Uruguay Round," Worid Economy (June 1988), pp. 217-31. . Protecting Intellectual Property Rights: Issues and Controversies (American Enterprise Institute for Public Policy Research, 1987).

"Bugs that Divide." Economist, July 28, 1990, pp. 57-58.

Butler, Alison. "Endogenous Innovation in a North-North Model of the Product Cycle," Federal Reserve Bank of St. Louis Working Paper 90-007 (1990).

Chin, Judith C., and Gene Grossman. "Intellectual Property Rights and North-South Trade," Princeton University Discus. sion Papers in Economics, No. 143 (November 1988).

Congress and the Nation. Vol. 6 (Congressional Quarterly Inc., 1985), p. 548 .

Diwan, Ishac, and Dani Rodrik. "Patents, Appropriate Technology, and North-South Trade," National Bureau of Economic Research Working Paper No. 2974 (May 1989).

Feinberg, Robert M. "Intellectual Property Injury, and International Trade," Journal of Wortd Trade (April 1988), pp. 45-56.

Feinberg, Robert M., and Donald J. Rousslang. "The Economic Effects of Intellectual Property Right Infringements," Journal of Business (January 1990), pp. 79-90.

Finger, Michael J., and Andrzej Olechowski, eds. The Uruguay Round: A Handbook on the Multilateral Trade Negotiations (The World Bank, 1987).

General Agreement on Tariffs and Trade. GATT: What it is, What it Does (1990).

Grossman, Gene M., and Elhanan Helpman. "Product Development and International Trade," Journal of Political Economy (December 1989), pp. 1261-83.

Hood, Neit, and Stephen Young. The Economics of Multinational Enterprise (London: Longman Group United, 1979).

\footnotetext{
26This has recently occurred in Korea, which, according to a 1987 study by the International Trade Commission, was the third-largest source of U.S. losses resulting from violations of IPR. Recently, however, Korea has taken steps to improve its enforcement of IPR, and the number of patents issued in the United States to Korean nationals has risen substantially, although it is still small in absolute value (U.S. Department of Commerce, Patent and Trademark Office, 1989). Of course, U.S. pressure has provided additional impetus for Korea to increase IPR protection.
}

${ }^{27}$ For a review of some of the problems in negotiating IPR in the Uruguay Round, see Maskus (1990), Benko (1988) and Finger and Olechowski (1987). 
Kamien, Morton I., and Nancy L. Schwartz. Market Structure and innovation (London: Cambridge University Press, 1982).

Mansfield, Edwin. "Patents and Innovation: An Empirical Study," Management Sclence (February 1986), pp. 173-81.

Maskus, Keith. "Normative Concerns in the Internationa! Protection of Intellectual Property Rights;" paper prepared for meetings of the International Seminar in International Trade at the National Bureau of Economic Research (August 2-3, 1990).

. "Intelleciual Property," in Jeffrey J. Schott, ed, Completing the Uruguay Round: $A$ Results-Oriented Ap. proach to the GATT Trade Negotiations (Institute for International Economics, 1990), pp. 164m79.

Meessen, Karl M. "Intellectual Property Rights in International Trade," Journal of World Trade Law (February 1987), pp, 67-74.

Nordhaus, William D. fnvention, Growth, and Welfare: $A$ Theoretical Treatment of Technological Change (MIT Press, 1969).

"Patents for Pharmaceuticals." Financial Times, May 15, 1990
Plock, Ernest. "International Piracy of Motion Pictures," in Ann Main, "Pursuing U.S. Goals Bilaterally: Intellectual Property and 'Special 301',' Business America (September $25,1989)$, p. 7.

U.S. Department of Commerce, Patent \& Trademark Office. Commissioner of Patents and Trademarks Annual Report (January 1989).

United States International Trade Commission. "Foreign Protection of Intellectual Property Rights and the Effect on U.S. Industry and Trade." Report to United States Trade Representative, Investigation No. 332-245, Publication 2065 (February 1988).

World Intellectual Property Organization. General information pamphlet (Geneva, January 1990a).

. WIPO Newsletter (February 1990b).

Existence, Scope and Form of Generally intemationally Accepted and Applied Standards/Norms for the Pro. tection of intellectual Property (Geneva, September 1988).

Yuetter, Clayton. News Release. "Statement by Ambassador Clayton Yuetter Concerning intellectual Property Rights Protection," Office of United States Trade Representative (Aprif 7, 1986). 